\title{
Performance Analysis of a Reduced Switch Z-Source Inverter fed IM Drives
}

\author{
K. Srinivasan and Dr.S.S. Dash
}

\begin{abstract}
This paper investigates the performance of a 4-switch, 3-phase Z-source inverter (4S3P) fed cost effective induction motor (IM) drive system. In the proposed approach, instead of a conventional 6-switch, 3-phase inverter (6S3P) a 4-switch, 3-phase Z-source inverter is utilized. This reduces the cost of the inverter, the switching losses, and the complexity of the control algorithms and interface circuits to generate 6 PWM logic signals. Furthermore, the proposed Z-source inverter system employs a unique LC network in the de link and a small capacitor on the ac side of the diode front end. By controlling the shoot-through duty cycle, the $Z$-source can produce any desired output ac voltage, even greater than the line voltage. As a result, the new $Z$-source inverter system provides ride-through capability during voltage sags, reduces line harmonics, improves power factor and reliability, and extends output voltage range. Analysis, simulation, and experimental results will be presented to demonstrate these new features
\end{abstract}

Index Terms- z-source inverter, voltage sags, four-switch three-phase inverter, Harmonic distortion.

\section{INTRODUCTION}

In a traditional voltage source inverter, the two switches of the same phase leg can never be gated on at the same time, because, doing so would cause a short circuit (shoot-through) to occur that would destroy the inverter. In addition, the maximum output voltage obtainable can never exceed the dc bus voltage. These limitations can be overcome by the new $Z$-source inverter[1], that uses an impedance network (Z-network) to replace the traditional de link. The Z-source inverter advantageously utilizes the shoot-through states to boost the dc bus voltage by gating on both the upper and lower switches of a phase leg. Therefore, the Z-source inverter can buck and boost voltage to a desired output voltage that is greater than the available dc bus voltage. In addition, the reliability of the inverter is greatly improved, because the shoot-through can no longer destroy the circuit. Thus it provides a low-cost, reliable and highly efficient single-stage structure for buck and boost power conversion. The main circuits of the Z-source inverter and its operating principle have been described in[2]. This maximum constant boost control can greatly reduce the $\mathrm{L}$ and $\mathrm{C}$ requirements of the Z-network.

Manuscript received December 30, 2009.

K.Srinivasan, is research scholar of Sathyabama University Chennai, Tamilnadu, India. Presently working in valliammai engineering college (e-mail : omsrivas@yahoo.co.in).

Dr.S.S.Dash, Professor in Electrical Engineering Department, S.R.M University, Chennai-603203 Tamilnadu, India (e-mail: munu_dash_2k@yahoo.com).
Traditionally, 6switch, 3-phase (6S3P) inverters have been widely utilized for variable speed IM drives. These inverters have some drawbacks, which involve the losses of the six switches as well as the complexity of the control algorithms and interface circuits to generate six PWM logic signals. Recently, some efforts have been made on the application of 4-switch, 3-phase (4S3P) inverter for uninterruptible power supply and variable speed drives. Some advantages of the 4S3P inverter over the conventional 6S3P inverter such as, reduced price due to reduction in number of switches, reduced switching losses, reduced number of interface circuits to supply logic signals for the switches, simpler control algorithms to generate logic signals, less chances of destroying the switches due to lesser interaction among switches and less real-time computational burden.

The reduced switch Z-source inverter shown in Fig. 1 that uses an impedance network (Z-network) to replace the traditional dc link. The Z-source inverter advantageously utilizes the shoot-through states to boost the dc bus voltage by gating on both the upper and lower switches of a phase leg. Therefore, the Z-source inverter can buck and boost voltage to a desired output voltage that is greater than the available $\mathrm{dc}$ bus voltage. In addition, the reliability of the inverter is greatly improved because the shoot-through can no longer destroy the circuit. Thus it provides a low-cost, reliable and highly efficient single-stage structure for buck and boost power conversion. Currently, there are two existing inverter topologies used for adjustable speed drives: The conventional 3-phase Pulse Width Modulation (PWM) inverter and 3- phase PWM inverter with a dc-dc boost converter, the conventional PWM inverter topology imposes high stresses to the switching devices and motor and limits the motor's constant power speed ratio.

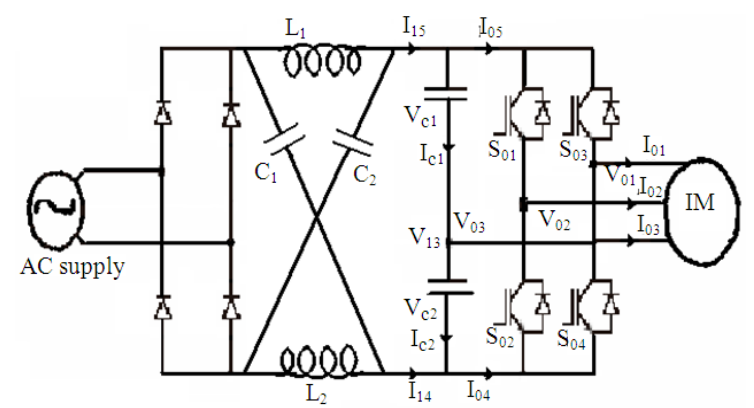

Fig. 1: System configuration using the reduced switch Z-Source Inverter fed IM drive.

The dc/dc boosted PWM inverter topology can alleviate the stresses and limitations, however, suffers from problems 
such as high cost and complexity associated with the two-stage power conversion[3]. The newly proposed reduced switch Z-Source Inverter fed IM drive has the unique feature that it can boost the output voltage by introducing shoot through operation mode, which is forbidden in traditional voltage source inverters. With this unique feature, the Z-source inverter provides a cheaper, simpler, single stage approach for applications of induction motor drives systems..

\section{Modeling OF The DRIVE System}

The complete drive system modeling involves the modeling of the inverter, Induction motor and Z-source inverter, which are discussed in the following subsections.

\section{A. Four switch three phase inverter model}

In the analysis, the inverter switches are considered as ideal power switches and it is assumed that the conduction state of the power switches is associated with binary variables $\mathrm{S}_{01}$ to $\mathrm{S}_{04}$. Therefore, a binary "1" will indicate a closed state, while "0" will indicate the open state[5]. Pairs $\mathrm{S}_{01}$ to $\mathrm{S}_{03}$ and $\mathrm{S}_{02}$ to $\mathrm{S}_{04}$ are complementary and as a sequence:

$$
\begin{aligned}
& \mathrm{S}_{03}=1-\mathrm{S}_{01} \\
& \mathrm{~S}_{04}=1-\mathrm{S}_{02}
\end{aligned}
$$

Also, it will be assumed that a stiff voltage is available across the two dc-link capacitors and:

$$
\mathrm{V}_{\mathrm{C} 1}=\mathrm{V}_{\mathrm{C} 2}=\overline{\mathrm{E}} / 2
$$

where, $\overline{\mathrm{E}}$ corresponds to a stiff dc-link voltage, i.e., the actual value of the dc-link voltage is equal to $\overline{\mathrm{E}}$. The phase voltage equations of the motor can be written as a function of the switching logic of the switches and the dc-link voltage and given by:

$$
\mathrm{V}_{\mathrm{a}}=\mathrm{V}_{\mathrm{dc}}\left(4 \mathrm{~S}_{\mathrm{a}}-2 \mathrm{~S}_{\mathrm{b}}-1\right) / 3
$$

TABLE 1: THE FOUR COMBINATIONS OF THE STATES OF THE POWER SWITCHES AND THE CORRESPONDING TERMINAL VOLTAGES $\mathrm{V}_{\mathrm{A}}, \mathrm{V}_{\mathrm{B}}$ AND $\mathrm{V}_{\mathrm{C}}$

\begin{tabular}{lllll}
\multicolumn{5}{c}{ ARE GIVEN IN TABLE 1 } \\
\hline $\mathrm{S}_{01}$ & $\mathrm{~S}_{02}$ & $\mathrm{~V}_{\mathrm{a}}$ & $\mathrm{V}_{\mathrm{b}}$ & $\mathrm{V}_{\mathrm{c}}$ \\
\hline 0 & 0 & $-\mathrm{U}_{\mathrm{c}} / 6$ & $-\mathrm{U}_{\mathrm{c}} / 6$ & $-\mathrm{U}_{\mathrm{c}} / 3$ \\
1 & 0 & $\mathrm{U}_{\mathrm{c}} / 2$ & $-\mathrm{U}_{\mathrm{c}} / 2$ & 0 \\
1 & 1 & $\mathrm{U}_{\mathrm{c}} / 6$ & $\mathrm{U}_{\mathrm{c}} / 6$ & $-\mathrm{U}_{\mathrm{c}} / 3$ \\
0 & 1 & $-\mathrm{U}_{\mathrm{c}} / 2$ & $\mathrm{U}_{\mathrm{c}} / 2$ & 0 \\
\hline
\end{tabular}

$$
\begin{gathered}
\mathrm{V}_{\mathrm{b}}=\mathrm{V}_{\mathrm{dc}}\left(-2 \mathrm{~S}_{\mathrm{a}}+4 \mathrm{~S}_{\mathrm{b}}-1\right) / 3 \\
\mathrm{~V}_{\mathrm{c}}=\mathrm{V}_{\mathrm{dc}}\left(-2 \mathrm{~S}_{\mathrm{a}}-2 \mathrm{~S}_{\mathrm{b}}+2\right) / 3
\end{gathered}
$$

Where:

$\mathrm{V}_{\mathrm{a}}, \mathrm{V}_{\mathrm{b}}, \mathrm{V}_{\mathrm{c}}=$ Inverter output voltages

$\mathrm{V}_{\mathrm{dc}}=\mathrm{Be}$ the voltage across the dc-link capacitors

$\mathrm{S}_{\mathrm{a}}, \mathrm{S}_{\mathrm{b}}=$ The switching functions for each phase leg

In matrix form, the above equations can be written as:

$$
\left[\begin{array}{c}
\mathrm{V}_{\mathrm{a}} \\
\mathrm{V}_{\mathrm{b}} \\
\mathrm{V}_{\mathrm{c}}
\end{array}\right]=\frac{\mathrm{V}_{\mathrm{dc}}}{3}\left[\begin{array}{cc}
4 & -2 \\
-2 & 4 \\
-2 & -2
\end{array}\right]\left[\begin{array}{l}
\mathrm{S}_{\mathrm{a}} \\
\mathrm{S}_{\mathrm{b}}
\end{array}\right]+\frac{\mathrm{V}_{\mathrm{dc}}}{3}\left[\begin{array}{c}
-1 \\
-1 \\
2
\end{array}\right]
$$

For a balanced capacitor voltage, the four switching combinations lead to four voltage reactors. Table 1 shows the different modes of operation and the corresponding output voltage vector of the inverter.

\section{B. Induction motor model}

The mathematical model of a three phase y connected induction motor and the load is given by the following equations in the d-q synchronously rotating reference frames as[6]:

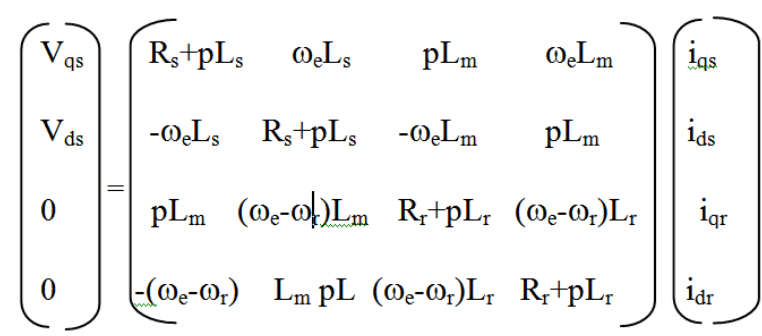

$\mathrm{T}_{\mathrm{e}}=(3 \mathrm{P} / 4) \mathrm{L}_{\mathrm{m}}\left[\mathrm{i}_{\mathrm{qs}} \mathrm{i}_{\mathrm{dr}}-\mathrm{i}_{\mathrm{ds}} \mathrm{i}_{\mathrm{qr}}\right]$

$\mathrm{T}_{\mathrm{e}}=\operatorname{Jm}\left(\mathrm{d} \omega_{\mathrm{r}} / \mathrm{dt}\right)+\mathrm{B}_{\mathrm{m}} \omega_{\mathrm{r}}+\mathrm{T}_{\mathrm{L}}$

$\mathrm{d} \theta_{\mathrm{r}} / \mathrm{dt}=\omega_{\mathrm{r}}$

Where:

$\mathrm{V}_{\mathrm{qs}}, \mathrm{V}_{\mathrm{ds}}=\mathrm{q}$, d-axis stator voltages

$\mathrm{i}_{\mathrm{qs}}, \mathrm{i}_{\mathrm{ds}}=\mathrm{q}, \mathrm{d}$ axis stator current

$\mathrm{I}_{\mathrm{qs}}, \mathrm{I}_{\mathrm{ds}}=\mathrm{q}, \mathrm{d}$ axis rotor current

$\mathrm{R}_{\mathrm{s}}, \mathrm{R}_{\mathrm{r}}=$ The stator and rotor resistances per phase

$\mathrm{L}_{\mathrm{s}}, \mathrm{L}_{\mathrm{r}}=$ The self inductances of the stator and rotor respectively

$\mathrm{L}_{\mathrm{m}}=$ The mutual inductance

$\omega_{\mathrm{r}}=$ The rotor speed

$\mathrm{p}=$ The number of poles

$\mathrm{p}=$ The differential operator

$\mathrm{T}_{\mathrm{e}}=$ The electromagnetic developed torque

$\mathrm{T}_{\mathrm{L}}=$ The load torque

$\mathrm{J}_{\mathrm{m}}=$ The rotor inertia

$\mathrm{B}_{\mathrm{m}}=$ The rotor damping co-efficient

$\theta=$ The rotor position

\section{Z-source model}

This Z-source inverter is used to overcome the problems in the traditional source inverters. This Z-source inverter employs a unique impedance network coupled with the inverter main circuit to the power source. This inverter has unique features compared with the traditional sources[3].

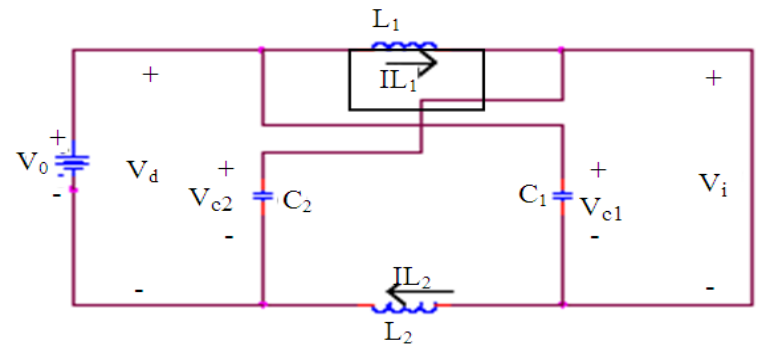

Fig. 2: Equivalent circuit of the impedance-source inverter

Impedance network, three phase inverter with induction 
motor load. AC voltage is rectified to dc voltage by the rectifier. This rectified output dc voltage is fed to the Impedance network consisting of two equal inductors $\left(\mathrm{L}_{1}, \mathrm{~L}_{2}\right)$ and two equal capacitors $\left(\mathrm{C}_{1}, \mathrm{C}_{2}\right)$. The network inductors are connected in series arms and capacitors are connected in diagonal arms. The impedance network buck or boost the input voltage depending upon the boosting factor. This network also acts as a second order filter. This network required less inductance and smaller in size. Similarly, capacitors required less capacitance and smaller in size ${ }^{[2]}$. The inverter main circuit consists of four switches. Gating signals are generated from the Discontinuous Pulse With Modulation (DPWM).

\section{Analysis of the z-source network}

Assume the inductors $\left(\mathrm{L}_{1}\right.$ and $\left.\mathrm{L}_{2}\right)$ and capacitors $\left(\mathrm{C}_{1}\right.$ and $\mathrm{C}_{2}$ ) have the same inductance and capacitance values respectively. From the above equivalent circuit:

$\mathrm{V}_{\mathrm{c} 1}=\mathrm{V}_{\mathrm{c} 2}=\mathrm{V}_{\mathrm{c}}$

$\mathrm{V}_{\mathrm{L} 1}=\mathrm{V}_{\mathrm{L} 2}=\mathrm{V}_{\mathrm{L}}$

$\mathrm{V}_{\mathrm{L}}=\mathrm{V}_{\mathrm{c}}, \mathrm{V}_{\mathrm{d}}=2 \mathrm{~V}_{\mathrm{c}}$

$\mathrm{V}_{\mathrm{i}}=0$

During the switching cycle T:

$\mathrm{V}_{\mathrm{L}}=\mathrm{V}_{\mathrm{o}}-\mathrm{V}_{\mathrm{c}}$

$\mathrm{V}_{\mathrm{d}}=\mathrm{V}_{\mathrm{o}}$

$\mathrm{V}_{\mathrm{i}}=\mathrm{V}_{\mathrm{c}}-\mathrm{V}_{\mathrm{L}} \mathrm{V}_{\mathrm{c}}-\left(\mathrm{V}_{\mathrm{o}}-\mathrm{V}_{\mathrm{c}}\right)$

$\mathrm{V}_{\mathrm{i}}=2 \mathrm{~V}_{\mathrm{c}}-\mathrm{V}_{\mathrm{o}}$

where, $\mathrm{V}_{\mathrm{o}}$ is the dc source voltage and:

$\mathrm{T}=\mathrm{T}_{\mathrm{o}}+\mathrm{T}_{1}$

The average voltage of the inductors over one switching period $(\mathrm{T})$ should be zero in steady state:

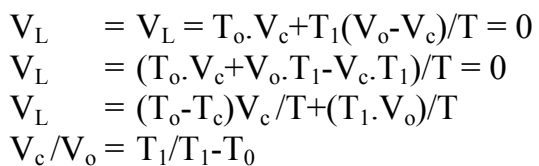

Similarly the average dc link voltage across the inverter bridge can be found as follows.

From Eq. 13:

$\mathrm{V}_{\mathrm{i}}=\mathrm{V}_{\mathrm{i}}=\left(\mathrm{T}_{\mathrm{o}} \cdot 0+\mathrm{T}_{1} \cdot\left(2 \mathrm{~V}_{\mathrm{c}}-\mathrm{V}_{\mathrm{o}}\right)\right) / \mathrm{T}$

$\mathrm{V}_{\mathrm{i}}=\left(2 \mathrm{~V}_{\mathrm{c}} \cdot \mathrm{T}_{1} / \mathrm{T}\right)-\left(\mathrm{T}_{1} \mathrm{~V}_{\mathrm{o}} / \mathrm{T}\right)$

$2 \mathrm{~V}_{\mathrm{c}}=\mathrm{V}_{\mathrm{o}}$

From Eq. 15:

$\mathrm{T}_{1} \cdot \mathrm{V}_{\mathrm{o}} /\left(\mathrm{T}_{1}-\mathrm{T}_{\mathrm{o}}\right)=2 \mathrm{~V}_{\mathrm{c}} \cdot \mathrm{T}_{1} /\left(\mathrm{T}_{1}-\mathrm{T}_{\mathrm{o}}\right)$

$\mathrm{V}_{\mathrm{c}} \quad=\mathrm{V}_{\mathrm{o}} \cdot \mathrm{T}_{1} /\left(\mathrm{T}_{1}-\mathrm{T}_{\mathrm{o}}\right)$

The peak dc-link voltage across the inverter bridge is:

$\mathrm{V}_{\mathrm{i}}=\mathrm{V}_{\mathrm{c}}-\mathrm{V}_{\mathrm{l}}=2 \mathrm{~V}_{\mathrm{c}}-\mathrm{V}_{\mathrm{o}}=\mathrm{T} /\left(\mathrm{T}_{1}-\mathrm{T}_{\mathrm{o}}\right) \cdot \mathrm{V}_{\mathrm{o}}=\mathrm{B} \cdot \mathrm{V}_{\mathrm{o}}(17)$

Where:

$\mathrm{B}=\mathrm{T} /\left(\mathrm{T}_{1}-\mathrm{T}_{\mathrm{o}}\right)$ i.e., $\geq 1$

$\mathrm{B}=\mathrm{A}$ boost factor

The output peak phase voltage from the inverter:

$\mathrm{V}_{\mathrm{ac}}=\mathrm{M} . \mathrm{Vi} / 2$ (18)

where, $\mathrm{M}$ is the modulation index.

In this source:

$\mathrm{V}_{\mathrm{ac}}=$ M.B. $\mathrm{V}_{\mathrm{o}} / 2$ (19)

In the traditional sources:

$\mathrm{V}_{\mathrm{ac}}=\mathrm{M} \cdot \mathrm{V}_{\mathrm{o}} / 2$

For Z-Source:

$\mathrm{V}_{\mathrm{ac}}=$ M.B. $\mathrm{V}_{\mathrm{o}} / 2$

The output voltage can be stepped up and down by choosing an appropriate Buck-Boost factor (BB):
$\mathrm{BB}=\mathrm{B} . \mathrm{M}$ (it varies from 0 to $\alpha$ )

The capacitor voltage can be expressed as:

$\mathrm{V}_{\mathrm{c} 1}=\mathrm{V}_{\mathrm{c} 2}=\mathrm{V}_{\mathrm{c}}=\left(1-\mathrm{T}_{\mathrm{o}} / \mathrm{T}\right) \cdot \mathrm{V}_{\mathrm{o}} /\left(1-2 \mathrm{~T}_{\mathrm{o}} / \mathrm{T}\right)$

The buck-boost factor BB is determined by the modulation index $\mathrm{m}$ and the boost factor B. The boost factor B can be controlled by duty cycle of the shoot through zero state over the non-shoot through states of the PWM inverter. The shoot through zero state does not affect PWM control of the inverter, because it equivalently produces the same zero voltage to the load terminal. The available shoot through period is limited by the zero state periods that are determined by the modulation index.

\section{Z-SOURCE INVERTER FED INDUCTION MOTOR}

The induction motor drive system suffers the following common limitations. The diode rectifier fed by the $230 \mathrm{~V}$ ac line produces about $310 \mathrm{~V}$ dc on the dc link, which is roughly 1.35 times the line to line input voltage under the assumption of heavy load. For small drives with no significant inductance, the line current becomes discontinuous and the dc voltage is closer to 1.41 times the line to line input voltage, the low output voltage significantly limits output power that is proportional to the square of the voltage. It is a very undesirable situation for many applications because the motor and drive system has to be oversized for required power. The voltage sags can interrupt an induction motor drive system and shut down critical loads and processes. The dc capacitor in induction motor drives is a relatively small energy storage element, which cannot hold dc voltage above the operating level under such voltage sags. Lack of ride through capacity is a serious problem for sensitive loads driven by drives ${ }^{[8]}$. Solutions have been sought to boost ride-through ${ }^{[2]}$. The industrial drives provide options using fly back converter or boost converter with energy storage to achieve ride-through; however, these options come with penalties of cost, size and complexity. Inrush and harmonic current from the diode rectifier can pollute the line. Low power factor is another issue of the traditional induction motor drives. Performance and reliability are compromised by the voltage source inverter structure, because miss matching from EMI can cause shoot-through that leads to destruction of the inverter, the dead time that is needed to avoid shoot-through creates distortion and unstable operation at low speeds and common-mode voltage causes shaft current and premature failures of the motor. A recently developed new inverter, the $\mathrm{Z}$ source inverter, has a niche for drives systems to overcome the aforementioned problems.

The Z-source inverter system can produce an output voltage greater than the ac input voltage by controlling the boost factor, which is impossible for the traditional induction motor drive systems. A Z-source inverter based induction motor drive can produce any desired output voltage, even greater than the line voltage, regardless of the input voltage, thus reducing motor ratings, provide ride-through during voltage sags without any additional circuits to improve power factor, reduce harmonic current and common-mode voltage. 
In this study, the implementation of the Four Switch Three Phase (FSTP) Z-source inverter fed induction motor using Atmel (AT89C2051) Microcontroller is presented.

\section{RESUlTS AND Discussion}

In order to verify the effectiveness of the inverter configuration and its control strategy, a computer simulation model is developed using the Matlab / Simulink software. Induction motor current waveforms and voltage waveforms of the Four Switch three phase Z-Source inverter are identical conditions with traditional six switch three phase inverter. It is evident that starting phase current is in the acceptable range. The steady state three phase current shown in Fig. 4b indicates almost balanced conditions of the four switch three phase inverter which is also verified by six switch three phase inverter response. The harmonic spectrum of a phase current Ia, for the FSTP Z source inverter is shown in Fig. 4d. The Total Harmonic Distortion (THD) of Ia is found $4.30 \%$ where as the THD of 6 switch three phase PWM inverter is found $8.70 \%$ as shown in Fig. 5 b.

The effectiveness of the Z-Source Inverters is proven by no overshoot, no undershoot and zero steady-state error of the speed response. It is also seen in Fig. 4c and Fig. $4 \mathrm{~d}$ that the speed response and the harmonic distortion of the FSTP-Z-Source inverter-based IM drive are also comparable to those of the conventional PWM inverter-based drive in Fig. $5 \mathrm{a}$ and $\mathrm{b}$. It is found that the performance of the four switch three phase inverter based drive is much close to that of the traditional 6 switches three phase inverter. The analysis and simulation results show that this inverter can dramatically reduce the complexity of the control algorithms and cost.

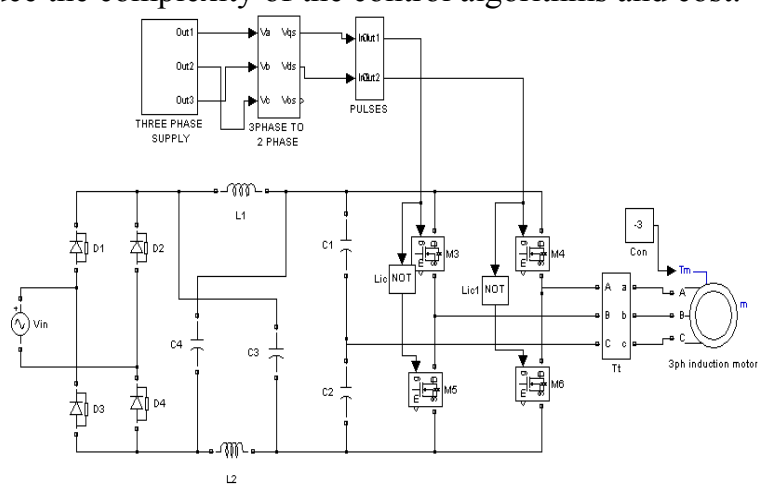

Fig. 3: FSTP Z-source inverters

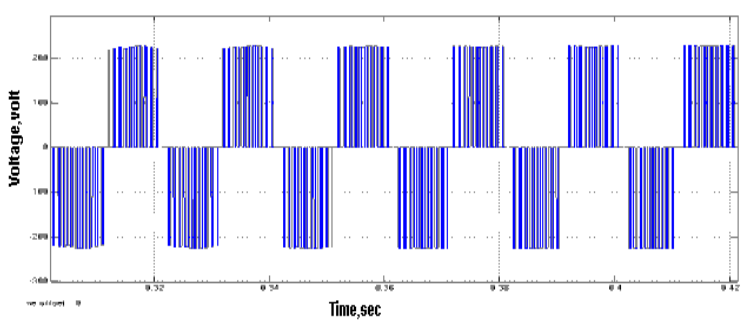

Fig. 4a FSTP Z-source inverter Voltage wave form

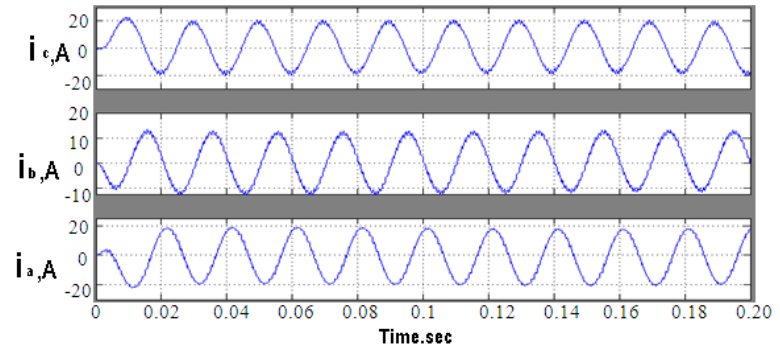

Fig 4b: FSTP Z-source inverter Stator currents

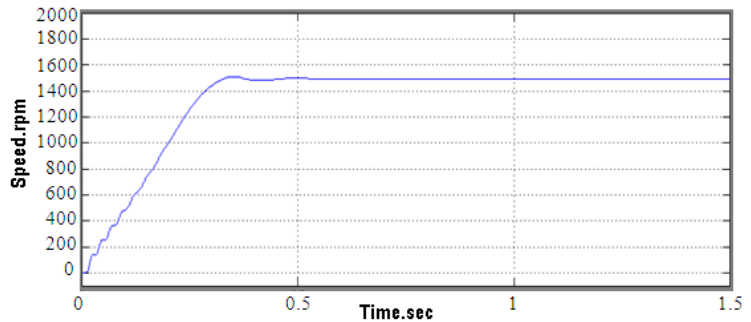

Fig 4c: FSTP Z-source inverter Speed response FFT analysis

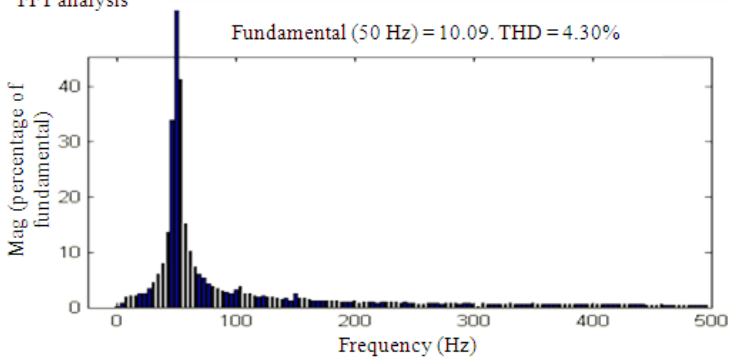

Fig. 4d: FSTP Z-source inverter Harmonic spectrum

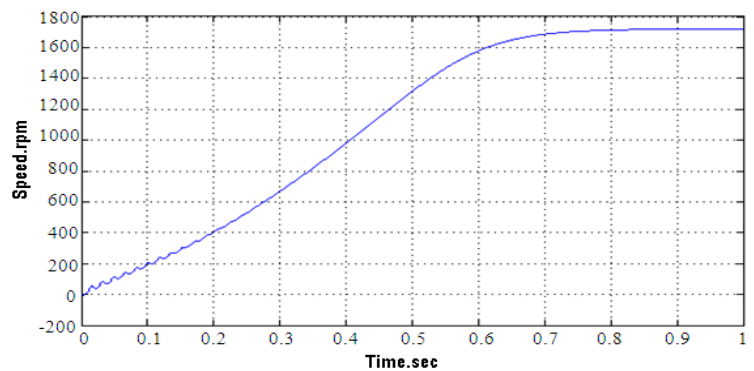

Fig 5a: Speed response of the conventional PWM inverter fed induction motor drive

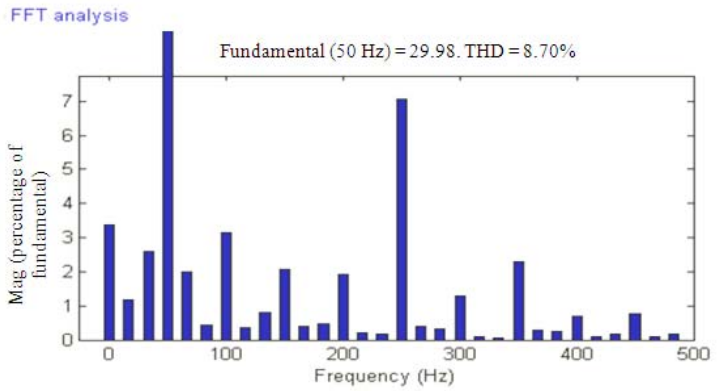

Fig. 5b: Harmonic spectrum of the conventional PWM inverter fed induction motor drive

\section{EXPERIMENTAL RESULTS}

A laboratory model has been built to verify the operation. The PWM control of the FSTP Z-source Inverter was tested using AT89C2051 micro controller and a three phase induction motor. In the experimental tests the load is a three phase induction motor (wound rotor, 0.5H.P). Figure 6 shows experimental waveform. The dc voltage across the bridge was boosted with a boost factor of 1.21. Also, it can be 
seen that the line current contains much less harmonics than the traditional ASD, although the wave shape is different from the simulation. This is because the line voltage is distorted in the lab, which was not considered in the simulation. Figure 6 shows the Laboratory model and experimental voltage waveform obtained with the FSTP Z-Source Inverter.
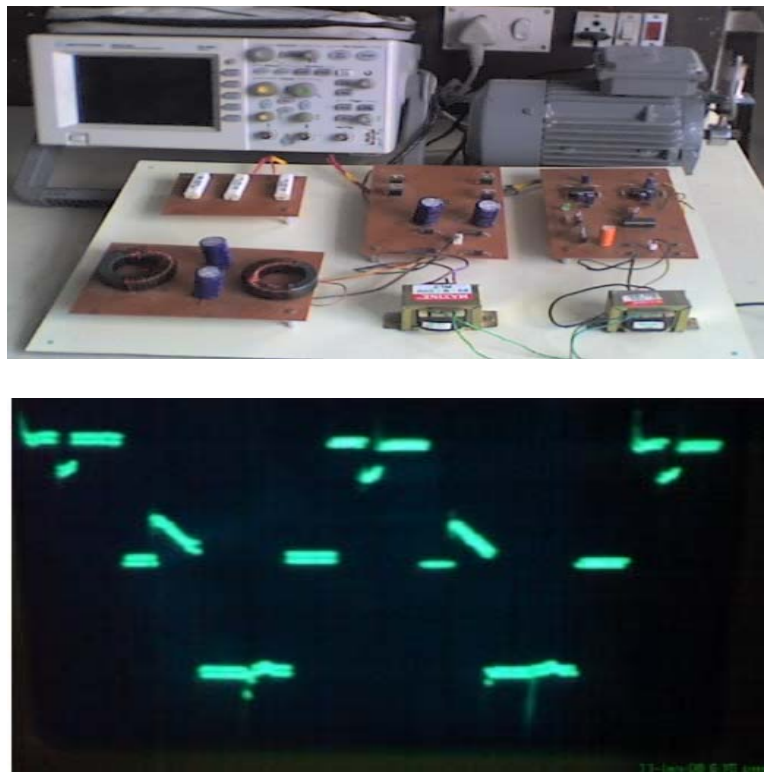

Fig. 6: Laboratory model and experimental voltages of the FSTP Z-source Inverters

\section{CONCLUSION}

This study has demonstrated that the component minimized Z-source inverter topology is a good alternative technology to the traditional inverter for more efficient, more reliable and less cost conversion systems. The operating principle and analysis have been given the current harmonics content simulation and experimental results verified the operational and demonstrated the promising features. In summary, the component minimized Z-source inverter ASD system has several unique advantages that are very desirable for many ASD applications:

- It can produce any desired output ac voltage, even greater than the line voltage

- Provides ride-through during voltage sags without any additional circuits and energy storage

- Minimizes the motor ratings to deliver a required power

- Reduces in-rush and harmonic current

- Unique drives features include buck-boost inversion by single power-conversion stage, improved reliability, strong EMI immunity and low EMI

The experimental results closely agree with the simulation results. The $\mathrm{Z}$-source converter employs a unique impedance network (or circuit) to couple the converter main circuit to the power source, thus providing unique features that cannot be observed in the traditional ac-ac converters. It can boost the input voltage, increase efficiency and reduce cost with minimized component count.

\section{REFERENCES}

[1] F. Z. Peng, "Z-Source Inverter," IEEE Transactions on Industry Applications, 39(2), pp. 504-510, March/April 2003. Wuhan, China

[2] Peng,F.Z., Miaosen Shen and Zhaoming Qian, 2004. "Maximum boost control of the z-source inverter". Proceeding of the IEEE PESC.

[3] Justus Rabi, B. and R. Arumugam, 2005. "Harmonics study and comparison of z-source inverter with traditional inverters". Am. J. Applied Sci., 2: 1418-1426.

[4] Pandian, G. and S. Rama Reddy, 2008. "Embedded controlled z source inverter fed induction motor drive “. J. Applied Sci. Res., 4: 826-832.

[5] Cruise,R.J.,C.F. Landy and M.D. McCulloch, 1999. "Evaluation of a reduced topology phase-converter operating a three-phase induction motor". Proceeding of the IEEE International Electric Machines and Drives Conference Seattle, WA., pp: 466-468.

[6] Nasir Uddin, M., T.S. Radwan and M.A. Rahman, 2004. "Performance analysis of four switch 3-phase inverter fed IM drives". Proceeding of the 3rd IEEE International Conference.

[7] Elbadsi, B., A. Guermazi and A. Masmoudi, 2005. "New space vector PWM strategy intended for a low-cost four-switch three-phase inverter-fed induction motor drive ". Proceeding of the CD-ROM of the 3rd IEEE International Conference on Systems, Signals and Devices, Sousse.

[8] Van Zyl, A., R. Spee, A. Faveluke and S. Bhowmik, 1998. "Voltage sag ride through for adjustable speed drives with active rectifiers". IEEE Trans. Ind. Appli., 34: 1270-1277.

[9] K. Stockman et al., "Bag the sags-Embedded solutions to protect textile process against voltage sags," IEEE Ind. Applicat. Mag., vol. 10, no. 5, pp. 59-65, Sep./Oct. 2004.

[10] M. Shen, J.Wang, A. Joseph, F. Z. Peng, L. M. Tolbert, and D. J. Adams, "Maximum constant boost control of the Z-source inverter," presented at the IEEE Industry Applications Soc. Annu. Meeting, 2004.

[11] Poh Chiang Loh, D. Mahinda Vilathgamuwa, Yue Sen Lai, Geok Tin Chua and Yunwei Li "Pulse-Width Modulation of Z-Source Inverters" IEEE Transaction on Power Electronics, Vol. 20, No. 6, November 2005.

[12] Arkadiusz Kulka, Tore Undeland." Voltage Harmonic Control of Z-source Inverter for UPS Applications" 13th International Power Electronics and Motion Control Conference (EPE-PEMC 2008), 672-677, 2008

[13] S. Thangaprakash,Dr. A. Krishnan."Z-source Inverter Fed Induction Motor Drives - a Space Vector Pulse Width Modulation Based Approach" Journal of Applied Sciences Research, Vol 5, No. (5): 579-584, 2009

[14] S. Thangaprakash,Dr. A. Krishnan."Modified Space Vector Pulse Width Modulation for Z-Source Inverters "International Journal of Recent Trends in Engineering, Vol 2, No. 6, November 2009

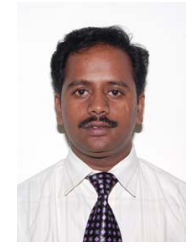

K.Srinivasan received the B.E. degree in Electrical and Electronics Engineering from University of Madras, Chennai, India in 1997, M.E. degree in Power Systems from Annamalai University, Chidambaram in 2001 and currently pursuing the $\mathrm{PhD}$ degree at Sathyabama University Chennai, India. He is presently working as Assistant Professor of EEE department at valliammai Engineering college, Chennai. His research interests are Inverters, motor drives and power conversion for alternative energy sources.

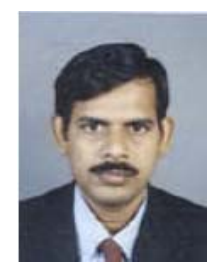

Dr.S.S. Dash is working as a professor in SRM University, Chennai, India. He is having more then 15 years of teaching and research experience. He has received M.E. degree in Power System Engineering from University college of Engineering, Burla, India in the year of 1996. He obtained $\mathrm{PhD}$ in Electrical Engineering from Anna University, Chennai, India in the year 2006. His current research interest includes FACTS, drives, AI techniques and power system stability. 